\title{
Pertanggungjawaban Pidana Nakhoda Kapal Asing Terhadap Pelanggaran Hukum di Wilayah Teritorial Indonesia
}

\author{
Eko Budi $\mathbf{S}^{1}$ \\ Fakultas Hukum Universitas Batanghari Jambi \\ Jl. Slamet Riyadi Broni, Kota Jambi Telp (0741) 65351 \\ Correspondence email: ekobudi1999@yahoo.co.id
}

\begin{abstract}
Abstrak. Sebagai negara kepulauan yang sangat luas Indonesia sangat strategis letaknya dalam rute perdagangan dunia, menjadikan perairan Indonesia memiliki beberapa permasalahan-permasalahan diantaranya masalah pencemaran lingkungan maritim dan keselamatan pelayaran. Permasalahan tersebut karena adanya minyak dari kapal, baik dari bahan bakar, dari dalam kamar mesin atau minyak sebagai kargo (muatan) yang mencemarkan lingkungan laut. Penelitian ini bertujuan untuk mengetahui pertanggungjawaban pidana Nakhoda kapal asing yang telah melanggar aturan tentang perlindungan dan pengelolaan lingkungan maritim serta pelayaran di Indonesia sedangkan manfaat penelitian ini adalah agar bertambahnya pemahaman bagi pengguna alur laut kepulauan Indonesia sehingga dapat berlayar dengan aman dan selamat. Metode penelitian yang digunakan adalah yuridis normatif sedangkan pemecahan masalahnya dengan concept approach dan case approach untuk menganalisis Putusan Pengadilan Negeri Batam Nomor 234/Pid.Sus/2021/PN. Btm terkait dengan penerapan pertanggungjawaban pidana Nakhoda kapal asing yang melanggar hukum di wilayah teritorial Indonesia. Hasil dari penelitian ini adalah dapat dipertanggungjawabkannya Nakhoda kapal asing yang melakukan pelanggaran hukum berdasarkan asas-asas hukum pidana yang diterapkan di Indonesia. Sehingga dapat disimpulkan bahwa seorang Nakhoda kapal asing yang telah berbuat kesalahan dapat dipidana dan mempertanggungjawabkan perbuatannya karena terdapat unsur-unsur pidana yang terpenuhi dan terbukti telah melanggar hukum di wilayah teritorial Indonesia.
\end{abstract}

Kata kunci: pertanggungjawaban, pidana, nakhoda, kapal.

\begin{abstract}
As a very large archipelagic country, Indonesia is very strategically located on world trade routes, making Indonesian waters have several problems including problems of maritime environmental pollution and shipping safety. This problem is due to the presence of oil from ships, either from fuel, from the engine room or oil as cargo that pollutes the marine environment. This study aims to determine the criminal responsibility of foreign ship captains who have violated the rules regarding the protection and management of the maritime environment and shipping in Indonesia, while the benefit of this research is to increase understanding for users of Indonesian archipelagic sea lanes so that they can sail safely and safely. The research method used is normative juridical while solving the problem with a concept approach and case approach to analyze the Batam District Court Decision Number 234/Pid.Sus/2021/PN. Btm is related to the implementation of criminal liability for foreign ship captains who violate the law in the Indonesian territory. The result of this research is that foreign ship captains can be held accountable for violating the law based on the principles of criminal law applied in Indonesia. So it can be concluded that a foreign ship captain who has made a mistake can be punished and accounted for his actions because there are criminal elements that are fulfilled and proven to have violated the law in the Indonesian territory.
\end{abstract}

Keywords: responsibility, criminal, captain, ship.

\section{PENDAHULUAN}

Sebagai negara maritim yang berbentuk kepulauan (archipelago state), keberadaan Negara Kesatuan Republik Indonesia di sepanjang garis khatulistiwa yang membentang sepanjang 5 ribu kilometer. Berada pada alur pelayaran internasional yang sangat ramai dengan situasi geostrategi dunia yang strategis, Indonesia berada pada posisi strategis antara dua benua yaitu Asia dan Australia serta diantara Samudera Pasifik dan Samudera Hindia. ${ }^{2}$

Konsep perairan kepulauan merupakan konsepsi yang telah termuat dalam Hukum Laut Internasional yang disebut dengan UNCLOS 1982. Konvensi tersebut menyatakan bahwa di perairan kepulauan seluruh kapal asing dapat menggunakan hak lintas alur laut kepulauan (sea lane passage) yang alurnya sudah ditentukan oleh negara kepulauan/pantai tersebut. Hak lintas tersebut dimaksudkan agar kapal-kapal asing dapat menempuh perjalanan yang lebih efektif dan efisien jika hendak berlayar dari laut lepas yang satu ke laut lepas lainnya melalui perairan kepulauan negara pantai.

Indonesia sebagai negara maritime telah mendapatkan pengakuan dunia Internasional, menjadikan perairan yang dulunya sebagai bagian dari laut bebas sekarang menjadi "perairan kepulauan". Sesuai konvensi Hukum Laut Internasional di perairan kepulauan, hak lintas damai (right of innocent passage) berlaku untuk seluruh kapal negara

${ }^{1}$ Dosen pada Fakultas Hukum Universitas Batanghari Jambi.

${ }^{2}$ Eka M. W, "Penegakan Hukum Di Laut Dengan Sistem Single Agency Multy Tasks", Rechtsvinding, Vol 3, No. 2, (Agustus 2014): 5. 
asing. ${ }^{3}$ Berdasarkan penjelasan UU RI Nomor 17 tahun 1985 tentang Ratifikasi Konvensi Hukum Laut Internasional, jika dianggap perlu untuk melindungi kepentingannya, negara kepulauan dapat menangguhkan sementara hak lintas damai di perairan kepulauan pada bagian-bagian tertentu. Pada negara pantai status perairan kepulauan termasuk ruang angkasa di atasnya dan dasar laut serta landan kontinennya memiliki kedaulatan penuh (sovereignity). Sehingga aturan negara pantai dapat diterapkan sepenuhnya di perairan kepulauan, kecuali terhadap kapal berbendera asing yang sedang berlayar di alur laut kepulauan.

Posisi Indonesia yang strategis letaknya dalam rute perdagangan dunia menjadikan perairan indonesia termasuk salah satu perairan yang tersibuk di dunia, sekitar $40 \%$ lebih perdagangan internasional melewati wilayah perairan Indonesia dari keseluruhan yaitu $90 \%$ perdagangan dunia. Sehingga memberikan dampak yang signifikan bagi kehidupan bangsa Indonesia. Adapun dampak positif positifnya adalah terdapatnya peluang ekonomi yang meningkat melalui lalu lintas perdagangan antar negara yang melalui laut kepulauan Indonesia. Selain dampak positif juga terdapat dampak negatif yaitu kurangnya kepatuhan dalam keselamatan pelayaran dan sumber daya kelautan berkurang akibat terbatasnya kemampuan aparat pemerintah dalam meindungi dan menjaga para pengguna alur laut yang menimbulkan pencemaran dilaut akibat dari lalu lintas pelayaran kapal-kapal tersebut.

Sebagai sarana dalam kegiatan angkutan di laut, kapal merupakan moda transportasi yang sangat potensial dimanfaatkan untuk transportasi dalam membangun dan meningkatkan kesejahteraan rakyat dan pembangunan nasional, disamping itu sebagai sarana pemersatu Negara. Undang-Undang Pelayaran mengamanatkan bahwa negara menjadi pengawaas dan pembina penyelenggaraan transportasi laut, karena peranannya yang sangat penting dan strategis serta transportasi laut keberadaannya telah menopang hajat hidup orang banyak, mulai dari buruh, karyawan kantor, operator alat transportasi, perusahaan sampai dengan pegawai negari. Namun karena luasnya lautan dan terbatasnya petugas keamanan laut, maka pengawasan dan perlindungan lingkungan laut/maritim masih kurang saat ini. Situasi tersebut ditambah lagi pengguna alat transportasi yang melintas di perairan Indonesia belum mengikuti aturan-aturan di laut, baik dalam perlindungan lingkungan maritim maupun keselamatan pelayaran.

Pencemaran di laut yang disebabkan karena minyak, dapat bersumber dari dari tangki bahan bakar kapal itu sendiri atau sisa penggunaan minyak yang berada di dalam ruang mesin maupun muatannya yang berupa minyak. Dampak dari pencemaran laut mempengaruhi terhadap segala kehidupan baik di laut maupun daratan yang terkena pencemaran. Saat ini, perairan yang kerap menjadi lokasi pembuangan tumpahan minyak ilegal atau sisa penggunaan bahan bakar kapal adalah perairan Kepulauan Riau dan sekitar Laut Natuna. Karena kapal yang masuk ke Singapura harus sudah bersih dari limbah maka banyak kapal-kapal asing membuang limbahnya di sekita perairan tersebut sebelum masuk.

Pelanggaran hukum baik pembuangan limbah dan pelanggaran pelayaran yang terjadi di perairan teritorial Indonesia, masih terus terjadi. Peran stakeholder yang menemukan langsung untuk melaporkan kepada petugas yang berwenang dan keaktifan para petugas penjaga keamanan laut di Indonesia. Salah satu pelanggaran hukum adalah pelangaran yang dilakukan oleh kapal MT. Freya GT. 160.216 berbendera Panama yang di Nakhodai oleh Chen Yiqun (CY) warga negara China. Hakim telah menyatakan bahwa Nakhoda kapal (CY) terbukti bersalah sebagaimana dalam dakwaan Penuntut Umum, telah melakukan tindak pidana pembuangan limbah ke laut dan pelanggaran pelayaran berdasarkan putusan hakim Pengadilan Negeri Batam Nomor 234/Pid.Sus/2021/PN Btm tanggal 17 Mei 2021.

Kemudian pelaku diancam dengan dua dakwaan, yang pertama dakwaan Primair Psl 104 UUPPLH jo Psl 55: (1) ke-2 KUHP. Keterangan ahli dari KLHK menyatakan bahwa limbah B3 yang telah dibuang oleh MT. Freya adalah minyak bumi (crude oil) dari kegiatan kilang Minyak Bumi yang termasuk limbah B3 dan memiliki kategori bahaya 1, yaitu limbah B3 tersebut dapat berdampak langsung terhadap manusia serta memiliki dampak negatif terhadap lingkungan hidup, keterangan ahli tersebut berdasarkan PP RI Nomor 101 Tahun 2014 tentang Limbah B3. Kapal tersebut tidak hanya membuang limbah B3, ternyata kapal tersebut juga telah melakukan pelanggaran pelayaran, sebagaimana dalam tuntutan Kedua Psl 317 Jo Psl 193: 1 (b) UU Pelayaran. Sehingga hakim memutuskan hukuman terhadap Terdakwa Chen Yiqun (CY) dengan hukuman penjara 1 (satu) tahun dengan masa percobaan selama 2 (dua) tahun serta terdakwa harus membayar denda sebesar Rp 2.500.000.000,- (dua milyar lima ratus juta rupiah). Perkara Nakhoda MT. Freya tersebut sempat mengundang perhatian nasional dan internasional sehingga Hakim sempat mengundur pembacaan Putusan PN Batam, karena harus hati-hati dan tepat dalam memutus perkara tersebut. Pada perkara tersebut Nakhoda kapal MT. Freya (CY) terbukti telah melanggar aturan perundang-undangan di wilayah teritorial Republik Indonesia dan Konvensi Hukum Laut Internasional tentang lintas alur laut kepulauan oleh kapal asing.

${ }^{3}$ M. Simanjuntak, Konvensi PBB 1982 Tentang Hukum Laut: Makna Dan Manfaatnya Bagi Bangsa Indonesia, (Jakarta: Mitra Wacana Media, 2018), hlm. 21. 
Dari kejadian tersebut, beberapa pengamat telah salah menilai peraturan internasional dan nasional karena menganalisanya sepenggal-pengal dan tidak komprehensif. ${ }^{4} \mathrm{Hal}$ tersebut karena logika mereka dalam membaca aturan hukumnya yang tidak menyeluruh, ditambah lagi ada kepentingan-kepentingan tertentu. Jika hal ini masih terjadi maka akan menimbulkan dampak negative terhadap apparat penegak hukum di Indonesia dan menurunkan reputasi penegakan hukum dimata dunia Internasional. Maka dari itu sangat penting sekali adanya sebuah analisa hukum yang komprehensif dan tepat dalam penanganan sebuah kasus yang menyangkut orang asing sehingga tidak menimbulkan penafsiran yang bermacam-macam. Maka dari itu inilah yang menjadi permasalahan dalam penulisan ini.

Dari uraian tersebut diatas, maka penulis melakukan analisis dengan fokus penelitian tentang tanggung jawab hukum oleh Nakhoda kapal asing MT. Freya (CY) yang telah melakukan tindak pidana berupa membuang limbah/pencemaran di laut serta kesalahan yang tidak mematuhi alur pelayaran Indonesia sesuai dengan undangundang pelayaran. Selain itu penelitian terhadap analisis pertanggungjawaban pidana oleh Nakhoda kapal asing MT. Freya (CY) belum pernah dilakukan sebelumnya. Sedangkan pembahasan penelitian ini akan membahas yang menjadi rumusan masalah tentang: 1) pertanggung jawaban pidana bagi Nakhoda MT. Freya yang merupakan kapal asing yang telah melakukan kesalahan melanggar hukum di wilayah teritorial Indonesia, 2) apasaja unsur-unsur pertanggungjawaban pidananya dan 3) pertimbangan hakim dalam memberikan pemidanaan terhadap perkara tersebut.

\section{METODE}

Metode penelitian yang digunakan adalah metode yuridis normatif sedangkan untuk analisisnya menggunakan concept approach dan case approach. Metode ini akan memberikan uraian analisis terhadap pertimbangan hukum oleh majelis hakim di Pengadilan Negeri Batam berdasarkan Putusan No. 234/Pid.Sus/2021/PN. Btm yaitu tentang penerapan pertanggungjawaban pidana Nakhoda kapal asing yang melanggar hukum di wilayah teritorial Indonesia berdasarkan UU tentang PPLH dan UU Pelayaran serta aturan yang terkait lainnya. Adapun sifat penelitiannya adalah diskriptif analitis yang memberikan penjelasan semua objek yang diteliti dengan cara menganalisis semua data-data yang telah didapat.

Yang digunakan untuk bahan pustaka adalah berupa data sekunder sebagai sumber utamanya, antara lain:

1. Undang-Undang tentang PPLH dan UU tentang Pelayaran serta peraturan yang terkait lainnya sebagai bahan hukum primer.

2. Buku, jurnal dan lain-lainnya yang menjelaskan mengenai bahan hukum primer sebagai bahan hukum sekunder, dan

3. Kamus, data internet dan lain sebagainya yang memberikan petunjuk bahan hukum primer dan sekunder, sebagai bahan hukum tertier.

Teknik pengumpulan data yang digunakan adalah studi kepustakaan, menurut Ronny teknik tersebut dapat diperoleh secara manual atau elektronik berupa putusan pengadilan, peraturan UU, buku-buku, jurnal serta data internet, ${ }^{5}$ Bahan analisis berupa putusan PN Batam Nomor 234/Pid.Sus/2021/PN. Btm yang didapat dari portal Putusan Mahkamah Agung RI melalui penelusuran data internet. ${ }^{6}$ Setelah bahan hukum dianalisis dengan menggunakan metode penafsiran hukum kemudian selanjutnya diambil kesimpulannya.

\section{HASIL DAN PEMBAHASAN}

\section{Pertanggungjawaban Pidana Nakhoda Kapal}

Dalam teori pertanggungjawaban pidana yang disampaikan oleh Simons, bahwa suatu upaya pemidanaan, yang telah dilihat secara umum atau dari segi pelakunya dapat diperbolehkan sehingga yang demikian kemampuan mempertanggungjawabkan dapat berarti sebagai suatu keadaan yang sedemikian rupa terhadap psikis seseorang. ${ }^{7}$ Sedangkan syarat, seseorang pelaku dapat dikatakan mampu bertanggungjawab jika seseorang tersebut diketahui bahwa kehendaknya sesuai dengan kesadarannya dan tahu/sadar bahwa perbuatannya tersebut dilarang oleh hukum.

Untuk dapat dipidananya seseorang dalam hal ini Nakhoda kapal, harus sudah ada perbuatan melawan hukum yang telah dilakukannya dan juga harus terbukti melakukan kesalahan terhadap perbuatan yang dilarang dalam undang-undang tersebut, pada perkara ini Nakhoda kapal MT. Freya (CY) telah melanggar Undang-Undang tentang

${ }^{4}$ Ari Afriansyah, Penegakan Kedaulatan di Laut dan Navigasi Kapal Asing, sumber Portal UI, https://law.ui.ac.id/v3/penegakan-kedaulatan-di-laut-dan-navigasi-kapal-asing-oleh-arie-afriansyah-s-h-m-i-l-ph-d/ diakses tanggal 17 September 2021, pukul 21.00 Wib.

${ }^{5}$ Ronny Hanitijo Soemitro, Metodologi Penelitian Hukum, (Jakarta: Ghalia Indonesia, 1990), hlm 45.

${ }^{6}$ Direktori Putusan Mahkamah Agung RI, Pidana https://Putusan3.mahkamahagung.go.id/direktori/putusan/zaebbf8d756b7d62b729313531393434.html, diunduh tanggal 23 Agustus 2021, pukul 21.00 Wib.

${ }^{7}$ Teguh Prasetyo, Hukum Pidana, (Depok: Raja Grafindo Persada, 2010), hlm. 85. 
PPLH serta melanggar UU Pelayaran. Adapun unsur penting dalam hukum pidana adalah kesalahan yang telah dilakukan oleh Nakhoda tersebut.

Pertanggungjawaban pidana sering dinamakan toeken-baardheid yaitu menuju kepada pemberian hukuman pelaku untuk menentukan seorang pelaku (Nakhoda) dapat dipertangungjawabkan atas suatu tindak pidana yang terjadi atau tidak. ${ }^{8}$ Pelaku tersebut akan mempertanggungjawabkan atas perbuatannya apabila melawan hukum dan tidak ada alasan pembenar atau peniadaan sifat melawan hukum dari perbuatannya, jika dilihat dari sudut terjadinya tindakan yang dilarang. Sedangkan jika dari segi kemampuan bertanggungjawab adalah hanya seseorang yang mampu bertangungjawablah yang bisa dipertangungjawabkan atas perbuatannya. ${ }^{9}$

Seorang Nakhoda dapat dipertanggungjawabkan pidana (verwijbaarheid) karena perbuatannya telah melawan hukum/wederrechtelijk. ${ }^{10}$ Tetapi bila perbuatan yang dilakukan Nakhoda tidak melawan hukum maka perbuatan yang melawan hukum tersebut tidak dapat dipertanggungjawabkan kepada Nakhoda. Maka untuk jaksa dapat melakukan penuntutan dengan memperhatikan unsur-unsur tindak pidana yang dimasukkan dalam surat tuntutan, dan kemudian dibuktikannya. Jika tidak dapat membuktikannya, maka hakim harus melepaskan terdakwa. Namun terkadang semua unsur pidana tersebut sudah terbukti, tetapi terhadap pelaku dilepaskan dari segala hukuman. Ini terjadi karena sifat perbuatan melawan hukumnya yang bersifat materiil tidak terbukti. ${ }^{11}$.

Menurut Satochid perbuatan yang telah melawan hukum belum tentu si pelaku tersebut dapat dipidana. ${ }^{12}$ Karena harus ada penyesalan dari pelaku terhadap kesalahannya dan pelaku memiliki kemampuan bertanggungjawab. Jadi terjadi pergeseran penafsiran hukum pidana, dimana pergeseran tersebut menekankan pada perbuatan seseorang beserta akibatnya bergeser kearah kesalahan orangnya dengan tanpa mengabaikan keberadaan perbuatannya itu sendiri. ${ }^{13}$

Dari analisis tersebut dapat ditarik kesimpulan bahwa seseorang Nakhoda kapal asing dapat dipidana harus memiliki kesalahan yang ada pada orang tersebut ketika seorang tersebut melakukan perbuatan melawan hukum baik secara formil maupun materiil. Jadi harus dapat mempertanggungjawabkan atas perbuatannya, tersebut. Sehingga jika seseorang (Nakhoda kapal) tidak memiliki kesalahan maka tidak dapat dia dipidana, tetapi karena Nakhoda tersebut memiliki kesalahan maka dapat dipidana untuk mempertanggungjawabkan perbuatannya.

\section{Unsur-unsur Pertanggungjawaban Pidana oleh Nakhoda Kapal}

Untuk menyatakan bahwa seorang Nakhoda memiliki kewajiban bertanggungjawab terhadap perbuatannya maka harus ada beberapa syarat yang harus terpenuhi untuk menyatakan bahwa Nakhoda dapat bertanggungjawab karena suatu pertanggungjawaban pidana adalah sebagai bentuk untuk menentukan apakah seorang Nakhoda akan dibebaskan atau dipidana atas tindak pidana yang telah dilakukan. Moeljatno berpendapat, bahwa selain harus ada kesalahan atau kesengajaan, pertanggungjawaban pidana tidak cukup dengan hanya dilakukannya perbuatan pidana saja. Selanjutnya sesuai dalam asas hukum oleh Moeljatno mengatakan bahwa suatu perbuatan yang tidak tertulis dalam undang-undang tidak dapat dihukum jika tidak ada kesalahan. ${ }^{14}$

Berdasarkan teori tersebut diatas, terhadap pasal 104 UUPPLH jo Psl 55: (1) ke-2 KUHP yang telah disangkakan kepada Nakhoda kapal MT. Freya. Setelah penulis analisis maka terdapat unsur-unsur yang memenuhi syarat sebagai kualifikasi delik pidana, yaitu sebagai berikut:

\section{Unsur persoonlijk/setiap orang}

Setiap orang dalam hal ini adalah pelaku sebagai subjek hukum yakni seorang (Nakhoda kapal asing) yang telah melakukan tindak pidana, ${ }^{15}$ dan Nakhoda tersebut dapat mempertanggung jawabkan perbuatan yang telah dilakukannya yang dalam hal ini adalah CY berdasarkan dakwaan Jaksa Penuntut Umum, dengan didampingi penterjemah bahasa Nakhoda tersebut mampu menjawab semua pertanyaan yang diajukan hakim kepadanya pada saat persidangan secara jelas dan rinci dan tanpa ragu tentang kemampuan bertanggung jawab pada diri Nakhoda tersebut serta tidak adanya alasan pemaaf dan alasan pembenar yang dapat menghapus kesalahannya maka terhadap Nakhoda tersebut dapat dipertanggungjawabkan atas perbuatan yang dilakukannya. ${ }^{16}$ Maka dapat dinyatakan bahwa unsur "setiap orang" telah terpenuhi.

${ }^{8}$ Eko Budi S, Pokok-Pokok Hukum Pidana: Dalam Teori dan Praktek, (Jambi: Salim Media, 2019), hlm.70.

${ }^{9}$ E.Y. Kanter dan S.R. Sianturi, Asas-Asas Hukum Pidana di Indonesia dan Penerapannya, (Jakarta: Storia Grafika, 2002), hlm. 165.

${ }^{10}$ Eko Budi S, Loc. Cit.

${ }^{11}$ Moeljatno, Asas-Asas Hukum Pidana, Edisi Revisi, (Jakarta: Renika Cipta, 2008), hlm. 73

${ }^{12}$ Satochid Kartanegara, Hukum Pidana, (Bandung: Balai Lektur Mahasiswa, 2002), hlm. 67.

${ }^{13}$ Bemmelen, Hukum Pidana, Jilid 1, (Jakarta: Binacipta, 1979), hal. 100.

${ }^{14}$ Moeljatno, Loc cit.

${ }^{15}$ Wirdjono Prodjodikoro, Asas-Asas Hukum Pidana di Indonesia, (Bandung: Refika Aditama, 2004), hlm. 89.

${ }^{16}$ Amir \& Haeranah, Hukum Pidana Materil \& Formil (Kesalahan dan Pertanggung jawaban Pidana), (Jakarta: USAIDThe Asia Foundation-Kemitraan Partnership, 2015), hlm. 8. 


\section{Unsur perbuatan}

Yaitu perbuatan dengan melakukan pencemaran dan pembuangan limbah ke laut tanpa izin. Unsur tersebut adalah salah satu unsur pokok dalam pertanggungjawaban pidana, yaitu perbuatan yang dilakukan pelaku merupakan perbuatan yang dilarang oleh undang-undang hal tersebut sesuai dengan asas legalitas yang dianut Indonesia karena seseorang tidak dapat dipidana apabila tidak melakukan suatu perbuatan. Sesuai pendapat Moeljatno asas legalitas artinya adalah perbuatan seseorang tidak dapat dipidana jika perbuatan itu tidak diatur dalam undang-undang. ${ }^{17}$

Unsur perbuatan yang dimaksud dalam perbuatan yang telah dilakukan oleh pelaku adalah melakukan pencemaran/dumping limbah yang dinyatakan dalam Psl 1 butir 24 UUPPLH adalah berupa kegiatan membuang, menempatkan, dan/atau memasukkan limbah dan/atau bahan dalam jumlah, konsentrasi, waktu, dan lokasi tertentu dengan persyaratan tertentu ke media lingkungan hidup tertentu. Dalam pembuktiannya sudah dilakukan pemeriksaan kepada para ahli dan berita acara pemeriksaan menjadi dasar dilakukannya penyidikan. Oleh majelis hakim perbuatan CY dinyatakan terbukti secara sah, yaitu pelaku telah melakukan perbuatan seperti yang dinyatakan oleh undang-undang tersebut.

\section{Unsur dengan sengaja}

Unsur tersebut maksudnya adalah pelaku dengan sengaja memberi sesuatu alasan, yaitu dengan menyalahgunakan kekuasaannya sebagai Nakhoda kapal dan sengaja menganjurkan kepada orang lain untuk membuang limbah tersebut. Yang dimaksud dengan menganjurkan adalah orang tersebut telah menyebabkan orang lain untuk berbuat tindak pidana. ${ }^{18}$ Adapun syarat penganjuran adalah ada penganjuran ketika pembuat materiil sudah melakukan kesalahan yang dianjurkan atau sudah ada percobaan untuk melakukan tindak pidana dan pembuat materiil tersebut dapat dipertanggungjawabkan, ada kesengajaan untuk menggerakkan orang lain untuk melakukan tindak pidana dan menggerakkannya dengan menggunakan sarana, putusan kehendak dari pembuat materiil sudah melakukan tindak pidana yang dianjurkan atau sudah ada percobaan melakukan tindak pidana.

Berdasarkan pengakuan Nakhoda CY (sebagai Terdakwa) telah memerintahkan Wang Wie Jie/WWJ (Saksi) selaku penanggung jawab pembuangan water ballast untuk membuang limbah ke laut tanpa menghidupkan mesin Oil Water Separator (OWS) sebagai penyaring minyak dan membuang atau dumping air limbah ke laut melalui buritan kanan kapal MT. Freya yang mengeluarkan cairan berwarna coklat/gelap yang seperti menyerupai minyak dan berbuih atau berbusa serta berbau menyengat seperti bau minyak yang tumpah ke laut, tindakan tersebut akhirnya diketahui oleh Kapal Patroli TNI AL pada tanggal 24 Januari 2021 dan telah dilakukan pemeriksaan awal, selanjutnya kapal diarahkan untuk sandar di pelabuhan terdekat untuk pemeriksaan lanjutan. Dalam pemeriksaan di persidangan Nakhoda mengatakan sengaja melakukan perintah tersebut kepada saksi WWJ dan saksi telah mengakuinya, maka unsur sengaja dalam hal ini terbukti secara syah.

Nakhoda Kapal MT. Freya selain didakwa melanggar UUPPLH juga didakwa secara subsider melanggar Pasal 317 Jo Pasal 193: (1) UU Pelayaran. Dari Putusan PN Batam tersebut kemudian dianalisis dengan teori pertanggungjawaaban pidana, maka didapatkan unsur-unsurnya antara lain:

\section{Unsur persoonlijk/setiap orang}

Setiap orang disini adalah pelaku sebagai Nakhoda MT. Freya (CY). "Nakhoda" berdasarkan Pasal 1 Angka 41 dalam UUP adalah salah satu dari awak kapal yang mempunyai wewenang dan tanggung jawab tertentu dan menjadi pemimpin tertinggi di kapal sesuai dengan ketentuan perundang-undangan. Bahwa Terdakwa CY adalah Nahkoda Kapal MT. Freya, maka dengan demikian unsur setiap orang ini telah terpenuhi.

\section{Unsur kesalahan yang tidak mematuhi alur pelayaran}

Yang dimaksud dengan kesalahan adalah keadaan psikologis seseorang yang berhubungan dengan perbuatan yang ia lakukan yang sedemikian rupa sehingga berdasarkan keadaan tersebut perbuatan pelaku dapat dicela atas perbuatannya yang melakukan pelanggaran alur pelayaran laut Indonesia. ${ }^{19}$ Sebelum menganalisis tentang kesalahan yang telah dilakukan oleh terdakwa CY (Nakhoda kapal MT. Freya), terlebih dahulu akan dibahas tentang alur pelayaran dan pengaturannya.

Alur Pelayaran dalam hal ini adalah perairan yang memiliki kedalaman, lebar dan merupakan bebas hambatan pelayaran lainnya dianggap aman dan selamat untuk dilayari oleh Kapal di laut, sungai atau danau. Pada Pasal 188 ayat (1) UUP menyebutkan "Penyelenggaran alur pelayaran diselenggarakan oleh Pemerintah", sedangkan dalam Pasal 188 ayat (3) UUP menyebutkan, untuk penyelenggaraannya Pemerintah wajib membuat alur pelayaran, sistim rute, mengatur tata cara berlalu lintas dan menetapkan daerah labuh kapal sesuai dengan kepentingannya. Selanjutnya Pasal 194 ayat (1) UUP menyebutkan "Pemerintah menetapkan Alur Laut Kepulauan

\footnotetext{
${ }^{17}$ Moeljatno, Op. Cit, hal. 74.

${ }^{18}$ Eko Budi S, Op. Cit., hlm. 103.

${ }^{19}$ Frans Maramis, Hukum Pidana Umum dan Tertulis di Indonesia, (Jakarta: Raja Grafindo Persada, 2012), hlm. 78.
} 
Indonesia dan tata cara penggunaannya untuk perlintasan yang sifatnya terus menerus, langsung dan secepatnya bagi kapal asing yang melalui perairan Indonesia”.

Yang menjadi pertimbangan bahwa kapal MT. Freya tidak dapat berlabuh atau berhenti diperairan sekitar Natuna dan Kepri adalah UU Nomor 17 Tahun 1985 tentang Pengesahan United Nation Covention On The Law Of The Sea 1982 (Konvensi PBB tentang Hukum Laut Internasional). Yang dimaksud dengan terus menerus, langsung dan secepatnya adalah kapal yang berlayar dari laut bebas melintas perairan Indonesia dan langsung menuju ke laut bebas lainnya. Sedang yang dinyatakan dalam Pasal 1 ayat (8) UU Nomor 6 Tahun 1996 tentang Perairan Indonesia (UUPI) dinyatakan bahwa, alur laut kepulauan merupakan alur laut yang diatasnya dilintasi oleh kapal atau pesawat udara asing, untuk melaksanakan aktifitas berupa pelayaran dan penerbangan secara normal hanya untuk singgah serta tidak langsung dan dengan cepat serta tidak diatas perairan kepulauan dan laut teritorial yang berada antara satu bagian laut lepas atau Zona Ekonomi Eklusif Indonesia dan bagian laut bebas atau Zona Ekonomi Eklusif Indonesia lainnya.

Dari berbagai aturan dan ketentuan diatas, maka mode transportasi yang melewati perairan Indonesia hanya boleh melintas di Alur Laut Kepulauan Indonesia (ALKI). Berdasarkan pemeriksaan dan pembuktian di persidangan, bahwa MT. Freya telah terbukti melakukan lego jangkar sehingga posisi kapal dalam keadaan berhenti di titik kordinat yang masih termasuk wilayah teritorial Indonesia tanpa izin dari otoritas yang berwenang. MT. Freya tersebut dengan sengaja telah mematikan AIS (Automatic Identification System). Kemudian pada deteksi secara visual posisinya berada diluar ALKI I (satu) dengan indikasi menutup semua nama, identitas kapal tidak menyala dengan posisi di titik koordinat $00^{\circ} 00^{\prime} 48^{\prime \prime} \mathrm{S}$ - $107^{\circ} 19^{\prime} 36^{\prime \prime}$ E berada diperairan Indonesia berdasarkan peta yang dikeluarkan oleh TNI Angkatan Laut. Di peta tercantum sebagai laut Natuna Selatan, berada di perairan pedalaman (bukan berada di pulau terluar), di sebelah barat Pontianak dengan jarak 7 mil dari pulau Pejantan. Bahwa identitas kapal yang ditutup adalah seluruh papan nama (nama kapal, lambung, buritan dan atas) nomor IMO ditutup, AIS (Automatic Identificaton Sytem) untuk pemantauan otomatis diatas kapal dimatikan, kemudian kapal MT. Freya melaksanakan lego jangkar diperairan tersebut dan kapal lainnya (MT. Horse) melaksanakan transfer crude oil (minyak mentah) ke kapal MT. Freya dengan tidak mengibarkan bendera kebangsaan.

Kemudian petugas pemeriksa dari Kapal TNI AL melakukan pemeriksaan pendahuluan dan ditemukan bahwa kapal MT. Freya telah membawa muatan antara lain muatan minyak mentah (Crude Oil) 166.129 MT dengan dilengkapi dokumen manifest (tanpa tempat tujuan) dan untuk ABK di daftar crew list terdapat 53 orang. Dari uraian dan pertimbangan diatas keberadaan Kapal MT. Freya yang berada diluar Alur Laut Kepulauan Indonesia dan berhenti melakukan Ship To Ship dengan kapal lainnya tidak sesuai dengan Alur Pelayaran dan telah melanggar aturan bagi kapal asing yang berlayar di perairan Indonesia.

Aturan di laut Indonesia, sebagian besar mengikuti aturan internasional. Dalam Pasal 18 (2) UNCLOS 1982, dikatakan bahwa "Passage shall be continuous and expeditious. However, passage includes stopping and anchoring, but only in so far as the same are incidental to ordinary navigation or are rendered necessary by force majeure or distress or for the purpose of rendering assistance to persons, ships or aircraft in danger or distress." Dari ketentuan ini jelas bahwa kalaupun kapal asing yang sedang berlayar melewati untuk hak lintas damai, hanya boleh melakukan pemberhentian atau lego jangkar jika kegiatan tersebut merupakan "incidental to ordinary navigation". Jadi hanya dalam keadaan incidental atau sesekali atau diperlukan dalam berlayar. Dalam hukum nasional, sudah jelas dalam Peraturan Pemerintah Nomor 36 tahun 2002 tentang hak dan kewajiban kapal asing dalam melaksanakan lintas damai melalui perairan Indonesia, Pasal 3 Ayat 4 dikatakan bahwa "Dalam melaksanakan Lintas Damai, kapal asing tidak boleh menurunkan sauh, berhenti, mondar-mandir, kecuali hal itu perlu dilakukan karena keadaan yang memaksa atau marabahaya atau karena menolong orang, kapal atau pesawat yang dalam keadaan berbahaya, sedangkan bagi kapal asing yang memang berniat untuk melakukan pemberhentian dan lego jangkar, maka sudah seharusnya mendapatkan izin dari otoritas negara pantai demi alasan keamanan pelayaran.

Dari pembahasan diatas maka unsur-unsur pertanggungjawaban pidana berupa kesalahan dari Nakhoda kapal MT. Freya (CY) tersebut adalah tidak melaksanakan aturan perundang-undangan tentang perlindungan maritim dan tata cara berlalu lintas di alur pelayaran, sistem rute, daerah pelayaran lalu lintas kapal, dan sarana bantu navigasi pelayaran merupakan satu kesatuan yang tidak dapat dipisahkan, sehingga apabila salah satu telah terbukti maka unsur tersebut telah terpenuhi.

\section{Pertimbangan Hakim Dalam Memutus Perkara}

Seorang Hakim harus mengambil keputusan yang tepat untuk menjatuhkan sanksi kepada terdakwa setelah proses di persidangan selesai. Hakim harus menelaah terlebih dahulu tentang kebenaran peristiwa yang diajukan kepadanya dengan melihat berbagai macam bukti yang ada dan disertai keyakinan dengan mengunakan metode penafsiran, kontruksi, dan mempertimbangan keadaan sosio-koltural untuk memenuhi kebutuhan seseorang. Atas 
peristiwa yang terjadi serta memghubungkan dengan hukum yang berlaku dan selanjutnya memberikan suatu kesimpulan dengan menetapkan suatu sanksi terhadap perbuatan pidana yang dilakukan oleh terdakwa setelah itu mempertimbangkan dan memberikan penilaian. Setelah dilakukan analisis terhadap Putusan PN Batam Nomor 234/Pid.Sus/2021/PN. Btm, maka dapat dijelaskan pertimbangan hakim dalam menjatuhkan pidana kepada Nakhoda kapal MT. Freya, adalah sebagai berikut:

\section{Pertimbangan Yuridis}

Dalam pertimbangan yuridis, JPU dapat menuntut terdakwa dengan tuntutan yang diatur dan diancam pidana sesuai Pasal 104 UUPPLH jo Pasal 55 ayat (1) ke-2 KUHP serta Pasal 317 Jo Pasal 193 Ayat 1 Huruf b UU tentang Pelayaran dan menjatuhkan pidana terhadap Terdakwa Nakhoda kapal MT. Freya (CY) dengan pidana penjara selama 1 (satu) tahun dengan masa percobaan selama 2 (dua) tahun dan menjatuhkan pidana denda terhadap Terdakwa sebesar Rp. 2.500.000.000,- (dua milyar lima ratus juta rupiah).

Hakim kemudian mempertimbangkan tuntutan JPU, berdasarkan fakta-fakta persidangan dan fakta-fakta hukum bahwa perbuatan terdakwa adalah salah dan terjadi kesengajaan berdasarkan unsur pasal undang-undang tersebut diatas sesuai persangkaan JPU dan memutuskan perbuatan terdakwa yang diatur dan diancam pidana dalam pasal tersebut dengan pidana yang sama dengan tuntutan Jaksa Penuntut Umum yaitu 1 (satu) tahun dengan masa percobaan selama 2 (dua) tahun dan menjatuhkan pidana denda terhadap Terdakwa sebesar Rp 2.500.000.000,- (dua milyar lima ratus juta rupiah). Dalam amar putusannya juga Hakim memerintahkan untuk mengembalikan barang bukti berupa Kapal MT. Freya beserta seluruh dokumen kapal dan muatan dikembalikan kepada terdakwa serta membebani Terdakwa membayar biaya perkara sebesar Rp.5.000,00 (lima ribu rupiah).

\section{Pertimbangan Non Yuridis}

Pertimbangan yuridis saja tidaklah cukup untuk menentukan nilai keadilan dalam menjatuhkan putusan pada pelaku tindak pidana lingkungan hidup dan pelayaran yang dapat membahayakan kehidupan manusia dan membahayakan kapal-kapal yang melintas. Pertimbangan non-yuridis oleh hakim dibutuhkan oleh karena itu masalah tanggung jawab hukum yang dilakukan oleh terdakwa tidaklah cukup kalau hanya didasarkan pada segi normatif dan masalah kerugiannya saja, tetapi faktor intern dan ekstern terdakwa yang melatar belakangi dalam melakukan kejahatan juga harus ikut dipertimbangkan secara arif oleh hakim yang mengadili.

Aspek sosiologis berguna untuk mengkaji latar belakang mengapa Nakhoda membuang limbah, aspek psikologis berguna untuk mengkaji kondisi psikologis terdakwa pada saat melakukan suatu tindak pidana dan setelah menjalani pidana sedangkan aspek kriminologi diperlukan untuk mengkaji sebab-sebab seorang melakukan tindak pidana dan bagaimana sikap serta prilaku terdakwa yang melakukan tindak pidana, dengan demikian hakim dapat memberikan putusan yang adil. Selanjutnya setelah dianalisis, bahwa putusan Hakim tersebut menggunakan pertimbangan non yuridis yaitu hal-hal yang memberatkan dan meringankan terdakwa. Hal-hal yang memberatkan terdakwa tercantum didalam putusan adalah bahwa perbuatan terdakwa dapat mengganggu keamanan dan keselamatan pelayaran. Sedangkan hal-hal yang meringankan terdakwa tercantum didalam putusan, bahwa terdakwa mengakui dan menyesali perbuatannnya, terdakwa tidak menyadari berada di perairan Indonesia dan terdakwa tidak ada niat melakukan kejahatan di wilayah perairan Indonesia.

Dari pembahasan tersebut, maka ketika akan menjatuhkan putusannya maka hakim harus mempertimbangkan landasan hukumnya, dalam teori ratio decidendi dijelaskan bahwa hakim dalam putusannya harus mempertimbangkan dasar hukum yang relevan dengan pokok perkara, dan motivasi hakim harus memiliki motivasi yang jelas untuk menegakkan hukum serta memberikan keadilan bagi para pihak yang terkait dengan pokok perkara. ${ }^{20}$ Maka dari itu hakim harus memperhatikan faktor-faktor kemanusiaan, kemanfaatan, penegakan hukum, dan kepastian hukum dalam setiap penjatuhan putusan. Maka menurut penulis, pertimbangan yang digunakan Hakim dalam memutus perkara yang dilakukan oleh Nakhoda MT. Freya (CY) sudah benar adanya berdasarkan surat dakwaan Jaksa Penuntut Umum dan fakta-fakta persidangan.

\section{SIMPULAN}

Setelah dilakukan pembahasan penelitian maka dapat disimpulkan sebagai berikut: 1) Nakhoda kapal asing yang berlayar di wilayah teritorial Indonesia dapat dimintakan pertanggungjawaban pidananya ketika seorang Nakhoda tersebut terbukti melakukan pelanggaran hukum nasional, karena perbuatannya telah terbukti baik secara formil maupun materil bersifat melawan hukum dan perbuatan yang telah dilakukan harus ada kesalahan yang melekat pada diri pelaku. Sehingga Nakhoda MT. Freya (CY) tersebut dapat dipidana dan harus mempertanggungjawabkan kesalahannya; 2) Unsur-unsur pertanggungjawaban pidana yang dilakukan oleh Nakhoda MT. Freya (CY) telah memenuhi unsur-unsur dalam undang-undang yang dikenakannya sehingga Nakhoda dapat dihukum. Unsur tersebut

\footnotetext{
${ }^{20}$ Ahmad Rifai, Penemuan Hukum oleh Hakim: Dalam Perspektif Hukum Progresif, (Jakarta: Sinar Grafika, 2010), hlm.
} 
antara lain bahwa "setiap orang" yaitu Nakhoda MT. Freya (CY) merupakan subyek hukum dalam hukum pidana di Indonesia, Nakhoda tersebut melakukan perbuatan yang salah sesuai aturan hukum di wilayah territorial Indonesia dan Nakhoda tersebut terbukti mampu mempertanggungjawabkan perbuatannya; 3) Hakim dalam memberi putusan telah sesuai dengan hal-hal yang meringankan dan memberatkan Nakhoda MT. Freya (CY) dengan berdasarkan aspek yuridis dan sosiologis.

\section{DAFATAR PUSTAKA}

\section{Buku}

Ahmad Rifai, Penemuan Hukum oleh Hakim: Dalam Perspektif Hukum Progresif, Jakarta, Sinar Grafika, 2010.

Amir Ilyas \& Haeranah, Hukum Pidana Materil \& Formil: Kesalahan dan Pertanggung jawaban Pidana, USAIDThe Asia Foundation-Kemitraan Partnership, 2015.

Bemmelen, Hukum Pidana, Jilid 1, Jakarta, Binacipta, 1979

Eko Budi Sariyono, Pokok-Pokok Hukum Pidana (Dalam Teori dan Praktek), Jambi, Salim Media, 2019.

E.Y. Kanter dan S.R. Sianturi, Asas-Asas Hukum Pidana di Indonesia dan Penerapannya, Jakarta, Storia Grafika, 2002.

Frans Maramis, Hukum PIdana Umum dan Tertulis di Indonesia, Jakarta, Raja Grafindo Persada, 2012.

Moeljatno, Asas-Asas Hukum Pidana, Edisi revisi, Jakarta, Renika Cipta, 2008.

Ronny Hanitijo Soemitro, Metodologi Penelitian Hukum, Jakarta, Ghalia Indonesia, 1990.

Satochid Kartanegara, Hukum Pidana, Bandung, Balai Lektur Mahasiswa, 2002.

Teguh Prasetyo, Hukum Pidana, Depok, Raja Grafindo Persada, 2010.

Wirdjono Prodjodikoro, Asas-Asas Hukum Pidana di Indonesia, Bandung, Refika Aditama, 2003.

\section{Peraturan Perundang-undangan}

Konvensi PBB tentang Hukum Laut Internasional 1982 (UNCLOS 1982)

Undang-Undang RI No. 1 tahun 1946 tentang KUHP

Undang-Undang RI No. 8 tahun 1981 tentang KUHAP

Undang-Undang RI No. 17 tahun 1985 tentang Ratifikasi UNCLOS 1982

Undang-Undang RI No. 6 tahun 1996 tentang Perairan Indonesia

Undang-Undang RI No. 17 tahun 2008 tentang Pelayaran

Undang-Undang RI No. 32 tahun 2009 tentang Perlindungan dan Pengelolaan Lingkungan Hidup

Undang-Undang RI No. 48 tahun 2009 tentang Kekuasaan Kehakiman

Undang-Undang RI No. 49 tahun 2009 tentang Peradilan Umum

Peraturan Pemerintah RI No. 36 tahun 2002 tentang Hak Dan Kewajiban Kapal Asing Dalam Melaksanakan Lintas Damai Melalui Perairan Indonesia

Peraturan Pemerintah RI No. 101 Tahun 2014 tentang Limbah Barang Berbahaya dan Beracun

\section{Jurnal/Makalah}

Eka M. W, "Penegakan Hukum Di Laut Dengan Sistem Single Agency Multy Tasks", Jurnal Online, Rechtsvinding BPHN, Vol 3, No. 2, (Agustus, 2014): 5.

\section{Internet}

Ari Afriansyah, Penegakan Kedaulatan di Laut dan Navigasi Kapal Asing, sumber Portal UI, https://law.ui.ac.id/v3/penegakan-kedaulatan-di-laut-dan-navigasi-kapal-asing-oleh-arie-afriansyah-s-h-m-i-lph-d/ diakses pada tanggal 17 Sebtember 2021, pukul 21.00 Wib.

Portal, Direktori Putusan Mahkamah Agung RI, Pidana Khusus, Sumber: https://putusan3.mahkamahagung.go.id/direktori/putusan/zaebbf8d756b7d62b729313531393434.html diunduh tanggal 23 Agustus 2021, pukul 21.00 Wib. 